\title{
Malignant Ovarian Luteinized Thecoma
}

National Cancer Institute

\section{Source}

National Cancer Institute. Malignant Ovarian Luteinized Thecoma. NCI Thesaurus. Code C6263.

A thecoma of the ovary that contains lutein cells and may metastasize to other anatomic sites. It is usually characterized by nuclear atypia and mitotic activity. 